\title{
Ecuador publications in the Science Citation Index Expanded: institutions, subjects, citation and collaboration patterns
}

\author{
Liria Calahorrano ${ }^{1}$, Julián Monge-Nájera ${ }^{2}$, Ming-Huang Wang ${ }^{3}$ \& Yuh-Shan $\mathrm{Ho}^{3 *}$ \\ 1. Department of Biotechnology, College of Health Science, Asia University, No. 500, Lioufeng Road, Wufeng, 41354 \\ Taichung, Taiwan; liria.calahorrano@gmail.com \\ 2. Laboratorio de Ecología Urbana, Vicerrectoría de Investigación, Universidad Estatal a Distancia, 2050 San José, Costa \\ Rica; julianmonge@gmail.com \\ 3. Trend Research Centre, Asia University, No. 500, Lioufeng Road, Wufeng, 41354 Taichung, Taiwan; \\ b88070554@gmail.com,ysho@asia.edu.tw \\ * Correspondence
}

Received 28-V-2019. Corrected 13-XI-2019. Accepted 16-I-2020.

\begin{abstract}
Introduction: Ecuador, a country of 17 million inhabitants with a medium human development index of 0.75 , has a small scientific productivity in relation to its size and population. Objective: To analyze Ecuador publications in the Science Citation Index Expanded, focusing on productivity, subjects, institutions, citations, and trends. Methods: We analyzed scientific publications by authors from Ecuador from 1900 to 2017 in the Science Citation Index Expanded and compared it with other tropical countries. Results: We found 16 document types (7 806 articles). The three most productive institutions were Universidad San Francisco de Quito, Pontificia Universidad Católica del Ecuador, and Escuela Politécnica Nacional. USA and Spain were the most frequent collaborating countries. Most articles were in English and ecology, botany, and zoology were common, but no field produced over $8 \%$ of articles. However, ecology represents $11.3 \%$ of the total citations. The most cited papers in the database were from large international biology and physics projects with minimal participation of Ecuadorean scientists. Article citations occurs mostly after the SCI stops counting. Conclusion: Science in Ecuador is growing but needs to greatly increase collaboration among Ecuadorean institutions to reduce its dependence on foreing projects. However, this study did not include articles published by the hundreds of Ecuadorean journals not covered by the SCI Expanded.
\end{abstract}

Key words: Ecuador, Citation Indicators, bibliometry, tropical country.

Calahorrano, L., Monge-Nájera, J., Wang, M. H., \& Ho, Y. S. (2020). Ecuador publications in the Science Citation Index Expanded: institutions, subjects, citation and collaboration patterns. Revista de Biología Tropical, 68(1), 98-107.

In Latin America, scientific output generally matches the wealth of each country; for example, Brazil, Mexico, and Argentina have the highest gross domestic products and also produce the most scientific publications (Ciocca \& Delgado, 2017); the majority of these publications originate in big cities and in private universities (Aguillo, Ortega, Prieto, \& Granadino, 2007), with exceptions like Costa Rica, where most of the research is done and published by public universities (MongeNájera \& Ho, 2016).

Besides the number of articles, another parameter is Citation, often used (and misused) to judge results, productivity and research collaboration (Monge-Nájera, 2014; MongeNájera \& Ho, 2015), but real citations for Latin American publications are unknown because there is no comprehensive database for Latin American journals (Monge-Nájera 
\& Ho, 2016). In recent years, Google Scholar Citation, Microsoft Academic Research, Clarivate Analytics (Web of Science) and Scopus (Elsevier) have started competing in this field and hopefully this will lead to a better coverage of the region (Aguado-López, Becerril-García, Arriola, \& Martínez-Domínguez, 2014). Nowadays, the use of bibliometrics in science policy making and budget distribution decision is vital as it contributes to assure quality in a higher learning education and researcher systems (Weingart, 2005).

In the particular case of Ecuador, a country of 17 million inhabitants with a medium human development index of 0.75 , petrographical research by foreign scientists started over a century ago (Regel, 1902). However, 60 years later British and American geographers warned about the lack of knowledge on the country and summarized some fields for future research, particularly the highland (Sierra) problems, the Sierra-Coast relationship, areas of social development, and the banana industry (Preston \& Graham, 1961). In the 1970s, an improvement in libraries and repositories suggested new research opportunities (Rodriguez, 1973), but Ecuadorean universities focused on teaching existing knowledge, rather than on doing research to produce new knowledge (Ayala Mora, 2015). In the 1980s, several authors created a research guide to Andean history, highlighting the importance of local, provincial and regional archives, in addition to the big central repositories (Canedo, 1981).

Several government administrations have tried to start a research system in the country. The National Council of Universities and Polytechnic Schools was created in 1982 and it was the first institution to assign a percentage of the national budget to research (Law of Universities and Polytechnic Schools of Ecuador of 1982, 2000), followed by the National Council of Superior Education (CONESUP in Spanish), which promotes and supports scientific research in the educational institutes (Ley de Educación Superior -Ley No. 16. RO/77, 2000), like the 2008 National Constitution (Gobierno del Ecuador, 2008). At the time, an evaluation of 71 universities found that only 11 had research projects (CONESUP, 2009). Two years later, additional laws and a secretariat were created to encourage research (Del Pozo, 2010), furthermore, Project Prometheus was created to create scientific networks and to foment research in different areas (Ballesteros, Bracco, Cerna, Finzi, \& Vidari, 2016; Ramos, Castro, Escalante, \& Vispo, 2017; Alvarado et al., 2018). Another landmark was the categorization of universities that actively support research (Rivera García, Espinosa Manfugás, \& Valdés Bencomo, 2017).

There is a lack of studies about how these laws and institutions have affected science in Ecuador, but like other countries in the region, its output is growing. Nevertheless, Ecuador still has a low scientific participation in the Latin-American context, neighboring Peru published slightly more even though its Grow Domestic Product (GDP) is double than Ecuador's GDP. On the other hand, Colombia published five times more than Ecuador, with a GPD three times higher (Bastidas Jiménez \& Benites Medina, 2016; World Bank, 2017). In the period 1996-2017, Ecuadorean scientific output ranked $12^{\text {th }}$ in Latin America. The first country is Brazil with the greatest number of published articles as well as the highest GDP in the region (SJR, 2017).

The visibility of Ecuadorean research in Latin-American is low: according to Miguel (2011), only two journals were included in Scopus, three in Redalyc and 32 in Latindex, and the whole country only represented $0.4 \%$ of the total regional publication between 20052009. The situation has greatly improved in the last decade, to 82 journals in Latindex in 2014 (2.44\% of total indexed journals, AguadoLópez, 2014). When even non-indexed journals are included, the numbers are much higher: Ecuador publishes 510 journals in several fields: social sciences (33\%), natural and exact sciences $(27 \%)$ and multidisciplinary $(20 \%)$; however, only $6 \%$ of these are open access (Freire Andrade, Guerron Sierra, \& Gómez García, 2017). 
Ecuador is one of the 17 biodiversity megadiverse countries (Aguirre Mendoza, 2012; Aguirre Mendoza, Aguirre Mendoza, \& Muñoz, 2017) and conservation is a key research area. Nevertheless, research skills are still unsatisfactory: only half of professors are familiar with research regulations and have good use of statistical tools and nearly two thirds cannot write English and ignore procedures for research group creation (Bastidas Jiménez \& Benites Medina, 2016).

Finally, the few studies available on the particulars of Ecuadorean science have identified the three most productive institutions: Universidad San Francisco de Quito, Pontificia Universidad Católica del Ecuador and Escuela Politécnica Nacional (SánchezRiofrío, Guerras-Martín, \& Forcadell, 2015; Hernández-Alvarez \& Gomez, 2016; Rivera García, Espinosa Manfugás, \& Valdés Bencomo, 2017).

The objective of this study is to analyze Ecuador publications in the Science Citation Index Expanded, focusing on productivity, subjects, institutions, citations, and trends.

\section{MATERIALS AND METHODS}

We did an advanced search in the online Science Citation Index Expanded (updated September 10, 2018) with the country field: "Ecuador" and period 1900 to 2017, and used Microsoft Excel 2016 to code and analyze the results (for methodological details see Li \& Ho, 2008; Ho \& Fu, 2016). The impact factors $\left(I F_{2017}\right)$ are based on Journal Citation Reports (JCR) 2017. England, Scotland, Northern Ireland, and Wales were reclassified as United Kingdom (Chiu \& Ho, 2005); Zaire as Democratic Republic of the Congo (Pouris \& Ho, 2014); Federal Republic of Germany and West Germany as Germany (Ho, 2012); Greenland as Denmark; New Caledonia, French Guiana, and French Polynesia as France; Republic of the Congo Congo (Tchuifon Tchuifon, $\mathrm{Fu}, \&$ Ho, 2017); United Arab as United Arab Emirates; West Indies Associated States as Trinidad and Tobago; and Senegambia as Gambia and
Senegal. The first author, who is Ecuadorean, corrected database misspellings errors and variability in institutional names, for example Univ San Francisco, USFQ, and Univ San Francisco de Quito were recognized as Universidad San Francisco Quito (see Elango \& Ho, 2017).

The "reprint author" field is the corresponding author, thus this study used "corresponding author". If authorship is not defined as first or corresponding author, the first author was defined as both, similar to single institutional articles (Ho, 2014).

The countries, institutions, and collaboration were obtained from the author's affiliation (Wang, Yu, \& Ho, 2010). "Country independent articles" and "single institute articles" were defined as "author's affiliation is from Ecuador" and "only one institute", respectively. "Internationally collaborative articles" means that the coauthors are from different countries and "inter-institutionally collaborative articles" that the coauthors are from different institutions inside Ecuador.

Other: $T C_{2017}$ means total citations from Web of Science Core Collection since publication to the end of 2017 (Wang, Fu, \& Ho, 2011; Chuang, Wang, \& Ho, 2011), $C_{2017}$ (citations in 2017), and $C P P_{2017}=T C_{2017} / T P$ were used to measure the citation rate (both developed by Ho, 2012). Terms like "classic articles" were defined as those with 1000 or more citations (summarized as " $T C_{2017} \geq 1000$ "; see Long, Huang, \& Ho, 2014) and "highly cited" as 100 or more citations in the Web of Science Core Collection, from publication to the end of 2017.

Relationship between percentage of publications and number of journals in productive Web of Science categories follows a proposal for search performances in tropical countries like Ghana (Boamah \& Ho, 2018), Guatemala (Monge-Nájera \& Ho, 2018), and Brunei (Ho, Lim, \& Monge-Nájera, 2018).

\section{RESULTS}

Document type and language of publication: A total of $16 \mathrm{Web}$ of Science document types were analyzed (Table 1, Digital 
Appendix); most were articles (81\% of 9658 documents), followed by meeting abstracts ( 9.5 $\%)$ and reviews $(4.1 \%)$. The mean number of authors per publication in corrections was 195, followed by articles with $A P P$ of 72 and data papers with $A P P$ of 24 . The most cited document type was Articles with $T C_{2017}$ of 119313. Book chapters had a $C P P_{2017}$ of 62 and Reviews a $C P P_{2017}$ of 27. The $C P P_{2017}$ of reviews was 1.8 times greater that of articles.

Additionally, 7806 articles were selected for further analysis because articles contain whole research ideas and results (Ho, Satoh, \& Lin, 2010). The main language was English (93 $\%$ ), followed distantly by Spanish (5.8 \%), and other languages such as Portuguese, French, German, and Italian.

The very small number of articles in the first part of the $20^{\text {th }}$ century did not represent a real absence of publications for Ecuador, as a quick search in Biological Abstracts can prove, it only means that the SCI Expanded practically did not cover that period.

Web of Science categories and journals: The first category is Ecology with 158 journals (Fig. 1, Digital Appendix), representing $7.7 \%$ of the total articles, followed by environmental sciences $(6.1 \%)$, plant sciences $(5.7 \%)$, zoology $(5.2 \%)$, and public, environmental and occupational health $(4.3 \%)$. Ecology receives $11.3 \%$ of the total citations, followed by multidisciplinary sciences $(8.3 \%)$, and particles and fields physics $(5.7 \%)$. Trends in the last years showed an increase in the particles and fields physics field (4.8\%), multidisciplinary geosciences $(4.0 \%)$, and astronomy and astrophysics $(4.0 \%)$. Particles and field physics, tropical medicine, and ornithology have fewer journals, but the number of articles was high. The journals that published most of articles were Physical Review Letters, Physical Review D, and PLoS One (Table 2, Digital Appendix). The Ecuadorian journal, Revista Ecuatoriana de Neurologia published $1.3 \%$ of the articles in the neuroscience category. In the ornithology category, 84 articles (43.3\%) have been published in Ornitología Neotropical.
Current trends in ecuadorian science reflect that ecology, environmental sciences, and zoology are the most published fields (Fig. 2, Digital Appendix).

Citation life cycles of the most frequently cited articles: The article lifespan was over 70 years. The initial value for citations per publication was 0.67 , the peak of $C P P_{2017}$ was 3.0, achieved after two years (it decreases after three years). The top cited articles had a similar lifespan behavior. The article "Antibiotic resistance: The need for global solutions" (Laxminarayan et al., 2013) is still growing strongly in citations.

There were two "classic articles" (Table 3, Digital Appendix); one is "Preexposure chemoprophylaxis for HIV prevention in men who have sex with men" (Grant et al., 2010), where 2499 men and transgender women from six countries were pre-exposed to a combination of two oral antiretroviral drugs that were reported to provide protection against HIV infection in individuals with high risk of acquiring the virus; this article also ranks first in $C_{2017}$. The second, about $G_{\mathrm{ST}}$, a value used to measure genetic differentiation among subpopulations, was analyzed by Jost (2008), who proposed a new measure of genetic differentiation that is independent of heterozygosity. Additionally, the majority of the top cited articles are related to biodiversity and ecology.

\section{Characteristics of publication outputs} and citation impact: Ecuador publications included in the database since 1900 are shown in Fig. 3, Digital Appendix. Two early papers included in the database are "Yellow fever control in Ecuador: Preliminary report" (Connor, 1920) and "Hookworm and other intestinal parasites in Ecuador" (Royer, 1920), both in the Web of Science category "General and Internal Medicine". After those two, the publications can be divided into three periods based on the political changes in the education system, the first period from 1920 to 1980 had 83 articles that got included in the database (Fig. 3, Digital Appendix), the second period from 1981 to 
2008 with a total of 2302 articles, and the last period from 2009 to 2017 with a total of 5421 articles (Fig. 4, Digital Appendix).

The publications covered in the database have been growing, the same as the citations per publication for journals, however, recent years have lower $C P P_{2017}$ s because the articles require time to accumulate citations. The $C P P_{2017}$ for the 7806 articles was 15 , the first peak in the number of citations per publication was caused by the article: "An unknown property of the calomel half-cell and the estimation of bromide-chloride mixtures" (Hahn, 1935) published by Escuela Politécnica Nacional. The second peak was due to "Microwear of mammalian teeth as an indicator of diet" (Walker, Hoeck, \& Perez, 1978) published in Science. The highest peak in 2004, in citations and articles, is proportional, even though only 16 articles are highly cited (Fig. 5, Digital Appendix). The most cited article in 2004 was "Effect of intravenous corticosteroids on death within 14 days in 10008 adults with clinically significant head injury (MRC CRASH trial) placebo-controlled trial" (Muzha et al., 2004), this article had 471 international collaborators, and studied 10008 adults.

\section{Collaborative countries and institutes:} National collaboration was small (Fig. 6, Digital Appendix), but collaboration with other countries was significant: 2872 publications (37\%) were made with American institutions and $20 \%$ with Spanish institutions (Table 4, Digital Appendix); of these, $17 \%$ of articles with American institutions had American researchers as first author or correspondence author, followed by Spain and France. Canadian collaboration had the highest $C P P_{2017}$ (38), but only represents $7.2 \%$ of the articles. Higher impact $\left(C P P_{2017}>30\right)$ collaborations were found with Argentina, Sweden, Netherlands, India, and the UK (collaboration with Spain had the lowest $\left.C P P_{2017}: 11\right)$.

The most prolific organizations are Universidad San Francisco de Quito (14 \% of total articles), Pontificia Universidad Católica del Ecuador (10\%), and Escuela Politécnica
Nacional (7.9\%) (Table 5, Digital Appendix). The first "independent institute" is Pontificia Universidad Católica del Ecuador, and the most collaborative institute is Universidad San Francisco de Quito. For the first author, corresponding author, and single author, Pontificia Universidad Católica del Ecuador ranked top.

Universidad San Francisco de Quito published most in the following categories (more than 100 articles): physics, particles and fields, astronomy and astrophysics, multidisciplinary physics, and nuclear physics. The Pontificia Universidad Católica del Ecuador published most in zoology and ecology categories. Finally, the Escuela Politécnica Nacional published most in the multidisciplinary geosciences' category.

\section{DISCUSSION}

Ecuador shares several publication trends with the tropical region: articles are the most frequent document type in the hard sciences, while books are common in the social sciences (Creamer, 1998). Book chapters and reviews receive more citations than other documents, probably because they are of general interest and thus have more readers (Monge-Nájera \& Ho, 2015). English completely dominated in our sample, because the majority of journals in the database are published only in English, but with nearly 500 journals not included in the index (Freire Andrade et al., 2017), it is probable that most of the Ecuadorian scientific output is published in Spanish and never gets covered by productivity and citation studies. This limitation applies to all results and analyses in this study.

Before 1980, there is no evidence that universities or government priorities were related to research, and the majority of publications entering the SCI Expanded were made by foreigners. Collins (1985) summarized the situation in the 1980s as follows: most applied science was directed to health and was conducted by government institutions that merely applied foreign techniques; researchers and students 
had to look abroad for proper education, facilities and support.

The historical trend for increased productivity may be related to the appearance of private institutions that include research in their budgets, and the budding consideration of research in government policies, but this was not part of our study and it can only be said that this growth matches what has happened everywhere else in Latin America (e.g. MongeNájera \& Ho, 2017a, 2017b, 2017c).

Ecuador participates in large, well financed international research projects centered in industrialized countries, in the fields of health and physics; this participation in foreign projects produces several types of bias in the results when an American database such as the Science Citation Index is used, mainly: it ignores all the research published in Spanish in local journals (not included in the database, thus underestimating productivity and citation by several magnitudes); it significantly raises mean values (e.g. number of authors per article, because these projects include as authors dozens or even hundreds of people who basically helped with samples or other limited aspects of research); it presents as "Ecuadorean publications" articles in which Ecuadorean authors had a small participation (often limited to collecting some samples added to a large pool of country samples). These biasses have to be borne in mind when considering the discussion that follows.

The 2004 peak in citations was for an article in which Ecuador only had a very limited participation and its high impact is explained by the practical nature of the study, about treatment of head injury victims: "Effect of intravenous corticosteroids on death within 14 days in 10008 adults with clinically significant head injury (MRC CRASH trial): Randomised placebo-controlled trial"; its controversial finding that corticosteroids increase mortality added to its appeal and later citation (Muzha et al., 2004; Kulkarni, Busse, \& Shams, 2007).

With no field representing more that 8 $\%$ of the research, Ecuador lacks the clear topic dominance that characterizes other under developed Latin American countries, often dominated by practical research in agriculture (Monge-Nájera \& Ho, 2017b), and El Salvador (Monge-Nájera \& Ho, 2017c). However, Ecuador may be known for its publications in Ecology that represents $11.3 \%$ of the total citations.

The unusual number of publications in fields in which Ecuador may be thought to lack world-class facilities, such as 'astronomy and astrophysics' and 'particles and fields physics' is particularly interesting. It appears to reflect both the collaboration of Ecuadorean scientists in large international projects, as well as the development of local infrastructure and talent. An example of collaboration is an article with 5111 authors, with one of them being from Ecuador and thus appearing in our study: "Measurements of the Higgs boson production and decay rates and constraints on its couplings from a combined ATLAS and CMS analysis of the LHC pp collision data at $=7$ and $8 \mathrm{TeV}$ " (Aad et al., 2016; this includes an address from the Universidad San Francisco de Quito). Similarly, García-Zorita, Marugán, and Filippo (2015) presented an increase in the authors means in the categories: Physics, particles and fields, astronomy, and astrophysics, multidisciplinary physics in Spain. The hyperauthorship -more than 100 authors- is common in the experimental fields, specially in Big Science collaborations.

An example of local infrastructure and talent is the establishment of a nuclear program in the Escuela Politécnica Nacional in the decade of 1950, a pioneering effort in a time in which nuclear energy was still new anywhere in the world. This Escuela is a public university that started operations in 1930.

Regarding citation, Ecuador's publications need two years to reach a citation peak, similar to countries like Guatemala (3 years) or Honduras (4 years), a period missed by the Science Citation Index, which only considers the first two years and thus produces results that are highly biased against Latin American journals (Monge-Nájera \& Ho, 2018; Monge-Nájera \& Ho, 2017b). The most cited articles are about HIV prevention (Grant et al., 2010), and the 
misused of a genetic indicator (Jost, 2008); in the first case, it has a small participation from Ecuador; in the second case, it corresponds to a foreign physicist and mathematician living in Ecuador associated with the Pontificia Universidad Católica del Ecuador for the last three years (Jost, 2019, personal communication).

In any case, Ecuador has a low level of internal collaboration, and a high proportion of articles in collaboration with the USA and Europe, typical of underdeveloped countries, while more advanced countries like Brazil have a much higher proportion of collaboration among institutions inside the country (MongeNájera \& Ho, 2018).

Ecuador has over 50 universities, but only three are highly visible in this particular database. The Escuela Politécnica Nacional is the only public institution among the top three; the others are private universities: San Francisco and Católica. The Universidad San Francisco de Quito, founded in 1988, asigns significant budgets to research, including libraries, museums and biological field stations, all with strong research links to institutions in the USA. The Pontificia Universidad Católica del Ecuador, founded in 1946, is part of the global network of Jesuitic institutions that traditionally support field work in natural history, research and the establishment of museums.

If the productivity of science in Ecuador is compared with that of Chile, another South American country, with similar population size, it seems to be low: for example, Chile has ten times more articles in the Scopus database (scimagojr.com, consulted May 18, 2019).

In conclusion, Ecuadorean science is growing and changing, the policies and budgets enlargements have increased the scientific output. The cooperation among Ecuadorean scientists is dismal, but the country has some highly productive institutions that publish quality research and cooperate strongly with foreign organizations. However, international collaboration in Big Science experiments in physics fields presented hyperauthorship, as well as health studies with large samples. The Ecuadorean science still has a long way to go, key points are national collaboration and international visualization (e.g. international journals publications).

Ethical statement: authors declare that they all agree with this publication and made significant contributions; that there is no conflict of interest of any kind; and that we followed all pertinent ethical and legal procedures and requirements. All financial sources are fully and clearly stated in the acknowledgements section. A signed document has been filed in the journal archives.

\section{ACKNOWLEDGMENTS}

We thank Lou Jost for graciously sharing information about his work.

\section{RESUMEN}

Publicaciones de Ecuador en el Índice de Citación de Ciencia: instituciones, categorías, citaciones y patrones de colaboración. Introducción: Ecuador es un país con 17 millones de habitantes y un indice de desarrollo humano medio de 0.75 , pero tiene una baja producción científica en relación con su tamaño y población. Objectivo: Analizar las publicaciones de Ecuador en el Índice de Citación de Ciencia enfocándose en la productividad, categorías, instituciones, citaciones y tendencias. Métodos: en la base de datos Science Citation Index analizamos las publicaciones científicas de autores con dirección ecuatoriana desde 1900 hasta 2017 y comparamos los resultados con otros países tropicales. Resultados: Encontramos 16 tipos de documentos (7 806 artículos). Las tres instituciones más productivas fueron Universidad San Francisco de Quito, Pontificia Universidad Católica del Ecuador, y Escuela Politécnica Nacional. Estados Unidos y España fueron los países con colaboración más frecuente. La mayoría de los artículos fueron escritos en inglés con Ecología, Botánica y Zoología como las categorías más comunes, pero ninguna supera una producción del $8 \%$ del total de las publicaciones. Sin embargo, Ecología representa el $11.3 \%$ del total de citaciones. Los artículos más citados en esa base de datos fueron de grandes equipos internacionales en Biología y en Física, con poca participación de científicos ecuatorianos. La mayoría de las citas se dan después de que el SCI detiene el conteo. Conclusión: La ciencia en Ecuador está creciendo, pero se necesita aumentar la colaboración entre las instituciones ecuatorianas para reducir la dependencia de proyectos extranjeros. Se debe considerar que este estudio no incluyó los artículos publicados por 
centenares de revistas ecuatorianas que no son cubiertas por el Science Citation Index.

Palabras clave: país tropical, Ecuador, indicadores de citación, bibliometría.

\section{REFERENCES}

Aad, G., Abbott, B., Abdallah, J., Abdinov, O., Abeloos, B., Aben, R., ... Woods, N. (2016). Measurements of the Higgs boson production and decay rates and constraints on its couplings from a combined ATLAS and CMS analysis of the LHC $p p$ collision data at $=7$ and $8 \mathrm{TeV}$. Journal of High Energy Physics, 2016(045), 1-113.

Aguado-López, E., Becerril-García, A., Arriola, M. L., \& Martínez-Domínguez, N. D. (2014). Ibero-America in mainstream science (Thomson Reuters/Scopus): A fragmented region. Interciencia: Revista de Ciencia y Tecnología de América, 39(8), 570-579.

Aguillo, I. F., Ortega, J. L., Prieto, J. A., \& Granadino, B. (2007). Web indicators for describing formal and informal scholarly communication in Latin America. Revista Española de Documentación Cientifica, 30(1), 49-60.

Aguirre Mendoza, Z. H. (2012). Diversidad Etnica-Cultural del Ecuador. Revista Estudios Universitarios, 2012, 164-173.

Aguirre Mendoza, Z., Aguirre Mendoza, N., \& Muñoz, C. J. (2017). Biodiversidad de la provincia de Loja, Ecuador. Arnaldoa, 24(2), 523-542.

Alvarado, A., Ruiz, M., Mothes, P., Yepes, H., Segovia, M., Vaca, M., ... Córdova, A. (2018). Seismic, volcanic, and geodetic networks in Ecuador: Building capacity for monitoring and research. Seismological Research Letters, 89(2), 432-439.

Ayala Mora, E. (2015). La investigación científica en las universidades ecuatorianas. Anales, 2015, 61-72.

Ballesteros, J. L., Bracco, F., Cerna, M., Finzi, P. V., \& Vidari, G. (2016). Ethnobotanical research at the Kutukú Scientific Station, Morona-Santiago, Ecuador. BioMed Research International, 2016, 1-18.

Bastidas Jiménez, M., \& Benites Medina, R. (2016). Impact of motivation in institutional scientific production. Retos-Revista de Ciencias de la Administración y Economía, 6(11), 67-89.

Boamah, P. O., \& Ho, Y. S. (2018). Bibliometric analysis of Ghana publications in the Science Citation Index Expanded. Revista de Biología Tropical, 66(1), 106-121.

Canedo, L. G. (1981). Research guide to Andean History. Bolivia, Chile, Ecuador and Peru. [Review of the
Book Research guide to Andean History. Bolivia, Chile, Ecuador and Peru by J. J. TePaske], The Americas, 38(2), 277-278.

Chiu, W. T., \& Ho, Y. S. (2005). Bibliometric analysis of homeopathy research during the period of 1991 to 2003. Scientometrics, 63(1), 3-23.

Chuang, K. Y., Wang, M. H., \& Ho, Y. S. (2011). Highimpact papers presented in the subject category of water resources in the Essential Science Indicators database of the Institute for Scientific Information. Scientometrics, 87(3), 551-562.

Ciocca, D. R., \& Delgado, G. (2017). The reality of scientific research in Latin America; an insider's perspective. Cell Stress \& Chaperones, 22(6), 847-852.

Collins, E. (1985). Research in Ecuador: Universities are squeezed. Nature, 318(6041), 9.

CONESUP, Consejo Nacional de Educación Superior (2009). Informe de Situación Académica y Jurídica de Universidades y Escuelas Politécnicas. Quito: CONESUP

Connor, M. E. (1920). Yellow fever control in Ecuador: Preliminary report. Journal of the American Medical Association, 74(10), 650-651.

Creamer, E. G. (1998). Assessing Faculty Publication Productivity: Issues of Equity. ASHE-ERIC Higher Education Report No. 26. Washington, DC: ASHE-ERIC/ George Washington University, Graduate School of Education and Human Development.

Del Pozo, H. (2010). Ley Orgánica de Educación Superior. Quito: Editorial Silec Profesional.

Elango, B., \& Ho, Y. S. (2017). A bibliometric analysis of highly cited papers from India in Science Citation Index Expanded. Current Science, 112(8), 1653-1658.

Freire Andrade, V., Guerron Sierra, A. V., \& Gómez García, A. R. (2017). Características editoriales de las revistas electrónicas ecuatorianas indexadas en Catálogo de Latindex. Revista Publicando, 10(1), 118-130.

García-Zorita, C., Marugán, S., \& Filippo, D. (2015). Coautoría e Hiper-autoría en la producción científica del Sistema Universitario Español. In J. Zabala Vázquez, R. Sánchez Jiménez, \& M. A. García Moreno (coords.), Desafios y oportunidades de las Ciencias de la Información y la Documentación en la era digital: actas del VII Encuentro Ibérico EDICIC 2015 (pp. 1-12). Madrid: Universidad Complutense de Madrid.

Grant, R. M., Lama, J. R., Anderson, P. L., McMahan, V., Liu, A. Y., Vargas, L., \& Glidden, D. V. (2010). Preexposure chemoprophylaxis for HIV prevention in men who have sex with men. New England Journal of Medicine, 363(27), 2587-2599. 
Gobierno del Ecuador. (2008). Constitución de la República del Ecuador. Quito: Asamblea Nacional Constituyente.

Hahn, F. L. (1935). An unknown property of the calomel half-cell and the estimation of bromide-chloride mixtures. Journal of the American Chemical Society, 57(9), 2537-2537.

Hernández-Alvarez, M., \& Gomez, J. M. (2016). Survey about citation context analysis: Tasks, techniques, and resources. Natural Language Engineering, 22(3), 327-349.

Ho, Y. S. (2012). Top-cited articles in chemical engineering in Science Citation Index Expanded: A bibliometric analysis. Chinese Journal of Chemical Engineering, 20(3), 478-488.

Ho, Y. S. (2014). Classic articles on social work field in Social Science Citation Index: A bibliometric analysis. Scientometrics, 98(1), 137-155.

Ho, Y. S., \& Fu, H. Z. (2016). Mapping of metal-organic frameworks publications: A bibliometric analysis. Inorganic Chemistry Communications, 73, 174-182.

Ho, Y. S., Lim, L. B. L., \& Monge-Nájera, J. (2018). Brunei publications in the Science Citation Index Expanded (1973-2016): Bibliometrics and comparison with other tropical countries. Revista de Biología Tropical, 66(3), 1090-1100.

Ho, Y. S., Satoh, H., \& Lin, S. Y. (2010). Japanese lung cancer research trends and performance in Science Citation Index. Internal Medicine, 49(20), 2219-2228

Jost, L. (2008). $G_{\mathrm{ST}}$ and its relatives do not measure differentiation. Molecular Ecology, 17(18), 4015-4026.

Kulkarni, A. V., Busse, J. W., \& Shams, I. (2007). Characteristics Associated with Citation Rate of the Medical Literature. PLoS ONE, 2(5), e403.

Law of Universities and Polytechnic Schools of Ecuador of 1982. (2000). SENESCYT. Retrieved from https:// www.educacionsuperior.gob.ec/wp-content/uploads/ downloads/2015/03/Ley-de-Universidades-19821. pdf

Laxminarayan, R., Duse, A., Wattal, C., Zaidi, A. K. M., Wertheim, H. F. L., Sumpradit, N., \& Cars, O. (2013). Antibiotic resistance: The need for global solutions. Lancet Infectious Diseases, 13(12), 1057-1098.

Ley de Educación Superior -Ley No. 16. RO/77. (2000). Quito, Ecuador. Retrieved from https:/www.oei. es/historico/quipu/ecuador/LEY_EDUCACION SUPERIOR.pdf

Li, Z., \& Ho, Y. S. (2008). Use of citation per publication as an indicator to evaluate contingent valuation research. Scientometrics, 75(1), 97-110.
Long, X., Huang, J. Z., \& Ho, Y. S. (2014). A historical review of classic articles in surgery field. American Journal of Surgery, 208(5), 841-849.

Miguel, S. (2011). Journals and scientific production in Latin America and the Caribbean: Its visibility in SciELO, RedALyC and SCOPUS. Revista Interamericana de Bibliotecología, 34(2), 187-198.

Monge-Nájera, J. (2014). La invalidez del Factor de Impacto como indicador del impacto de las revistas científicas latinoamericanas. Revista de Biología Tropical, 62(1), 407-412.

Monge-Nájera, J., \& Ho, Y. S. (2015). Bibliometry of Panama publications in the Science Citation Index Expanded: Publication type, language, fields, authors and institutions. Revista de Biología Tropical, 63(4), $1255-1266$.

Monge-Nájera, J., \& Ho, Y. S. (2016). Bibliometry of the Revista de Biología Tropical/International Journal of Tropical Biology and Conservation: Document types, languages, countries, institutions, citations and article lifespan. Revista de Biología Tropical, 64(3), $1223-1235$

Monge-Nájera, J., \& Ho, Y. S. (2017a). Bibliometrics of Nicaraguan publications in the Science Citation Index Expanded. Revista de Biología Tropical, 65(2), 643-655.

Monge-Nájera, J., \& Ho, Y. S. (2017b). Honduras publications in the Science Citation Index Expanded: institutions, fields and authors. Revista de Biología Tropical, 65(2), 657-658.

Monge-Nájera, J., \& Ho, Y. S. (2017c). El Salvador publications in the Science Citation Index Expanded: subjects, authorship, collaboration and citation patterns. Revista de Biología Tropical, 65(4), 1428-1436.

Monge-Nájera, J., \& Ho, Y. S. (2018). Guatemala articles in the Science Citation Index Expanded: bibliometry of subjects, collaboration, institutions and authors. Revista de Biología Tropical, 66(1), 312-320.

Muzha, I., Filipi, N., Lede, R., Copertari, P., Traverso, C., Copertari, A., ... Olldashi, F. (2004). Effect of intravenous corticosteroids on death within 14 days in 10008 adults with clinically significant head injury (MRC CRASH trial): Randomised placebo-controlled trial. Lancet, 364(9442), 1321-1328.

Pouris, A., \& Ho, Y. S. (2014). Research emphasis and collaboration in Africa. Scientometrics, 98(3), 2169-2184

Preston, D. A., \& Graham, A. M. S. (1961). Some fields of research in Ecuador. Professional Geographer, 13(2), 16-19.

Ramos, T. I., Castro, K. A., Escalante, L. S., \& Vispo, N. S. (2017). Advances in clinical research in Ecuador. 
Therapeutic Innovation \& Regulatory Science, 51(3), 307-313.

Regel, F. (1902). Ecuador 1870-1874. Petrographical research. Petermanns Mitteilungen, 48(5), 35-36.

Rivera García, C. G., Espinosa Manfugás, J. M., \& Valdés Bencomo, Y. D. (2017). Scientific research at Ecuadorean universities: A priority of the education in force. Revista Cubana de Educación Superior, 36(2), 113-125.

Rodriguez, J. E. (1973). New research opportunities in Ecuador. Latin American Research Review, 8(2), 95-100.

Royer, E. R. (1920). Hookworm and other intestinal parasites in Ecuador. JAMA-Journal of the American Medical Association, 75, 1702-1705.

Sánchez-Riofrío, A. M., Guerras-Martín, L. Á., \& Forcadell, F. J. (2015). Business portfolio restructuring: A comprehensive bibliometric review. Scientometrics, 102(3), 1921-1950.

SJR (2017). SCImago journal \& country rank. Retrieved from https://www.scimagojr.com/
Tchuifon Tchuifon, D. R., Fu, H. Z., \& Ho, Y. S. (2017). Cameroon publications in the Science Citation Index Expanded: Bibliometric analysis. Revista de Biología Tropical, 65(4), 1582-1591.

Walker, A., Hoeck, H. N., \& Perez, L. (1978). Microwear of mammalian teeth as an indicator of diet. Science, 201(4359), 908-910.

Wang, M. H., Fu, H. Z., \& Ho, Y. S. (2011). Comparison of universities' scientific performance using bibliometric indicators. Malaysian Journal of Library \& Information Science, 16(2), 1-19.

Wang, M. H., Yu, T. C., \& Ho, Y. S. (2010). A bibliometric analysis of the performance of Water Research. Scientometrics, 84(3), 813-820.

Weingart, P. (2005). Impact of bibliometrics upon the science system: Inadvertent consequences? Scientometics, 62(1), 117-131.

World Bank. (2017). GDP (current US\$). World development indicators. Retrieved from https://data.worldbank.org/indicator/ny.gdp.mktp.cd?

See Digital Appendix at: / Ver Apéndice digital en:

revistas.ucr.ac.cr 